(Barton) section is the clearly defined pebble-bed towards the higher part of the Highcliffe Sands of the Survey. The glauconitic clays above this bed are strongly contrasted with the pale sands below. The Nummulites Prestwichii band is met with a few feet above, and so the pebble-bed and the few feet of clays between it and the Nummulite band are usually grouped in the upper part of the Bracklesham Beds. This seems curious, since the zonal Nummulite does occur, though sparingly, below its special band. Moreover, there is no lithological change at the Nummulite band, but a very obvious one at the pebble-bed below. This pebble-bed may be the same as the one seen in Alum Bay at the base of the 47 feet of doubtful beds.

The marine Bartonian beds (Barton Clay and Barton Sands) thicken steadily eastwards from 192 feet at Highcliffe (Barton) to 338 feet in Alum Bay and 368 feet in Whitecliff Bay. The first two figures are increased to 206 and 385 feet respectively if the pebblebed is taken as the base of the Bartonian. The continental Bartonian (Lower Headon Beds) consists of freshwater limestones with Limnca, marls, etc., and thins, as one would expect, from west to east; $82 \frac{1}{2}$ feet at Barton, from 61 to 82 feet in Alum Bay and on Headon Hill; it is reduced to 28 feet in Whitecliff Bay, and has become more estuarine.

Commencing with the Middle Headon Beds, the Oligocene deposits of the Hampshire Basin also seem to group themselves into cycles. The distribution of the zones of the Middle Headon agrees with the theory of a gradual transgression at that period, similar to the transgression observed in the Landenian or Lutetian. It is hoped to deal later with these beds.

(To be concluded.)

\title{
The Unconformity between the Millstone Grit and the Carboniferous Limestone at Ifton, Mon.
}

\author{
By E. E. L. Dixox, A.R.C.Sc., B.Sc., F.G.S.
}

(PLATE II)

\section{IxTRODUCTION}

THE object of the present communication is to place on record a section, apparently unique, in which the unconformity between the Millstone Grit and Carboniferous Limestone that exists in parts of South Wales and Monmouthshire is clearly displayed. The exposure was first examined at the suggestion of the brilliant worker who threw so much light on Lower Carboniferous problems, the late Dr. Vaughan. The writer had explained ${ }^{1}$ the attenuation of the Carboniferous Limestone Series in the Newport (Mon.) district as due to unconformable overstep by the Millstone Grit, similar to

'In "The Country around Newport" (Mem. Geol. Surv.), ed. 2, 1909, p. 20. 
an overstep at this horizon that had already been observed near Haverfordwest, at the other end of the South Wales basin, by Professor 0. T. Jones. ${ }^{1}$ The value of the Ifton section in demonstrating that this overstep was widespread was recognized, and photographs, two of which are here reproduced, were secured by H.M. Geological Survey. Since then the unconformity at the eastern end of the South Wales coalfield has been confirmed by the detailed examination of a large area by Mr. F. Dixey and Dr. T. F. Sibly, ${ }^{2}$ and has been found by the writer, in the course of work not yet published, to reach its greatest known extent in the Abergavenny district. Nevertheless, it seems desirable to describe the Ifton section because it is the clearest exposure known, in the whole of the South-West Province, of the unconformity between the Carboniferous Limestone and the Millstone Grit, and also on account of the remarkable inter-relations of the two formations which it reveals.

It should be observed that though the Ifton limestone-outcrop is continuous with that surrounding the Forest of Dean coalfield, the sandstones spoken of as "Millstone Grit" in the two areas, which are widely discontinuous, differ completely from one another in age and character. Those of the Forest of Dean have been shown by Dr. Vaughan ${ }^{3}$ and by Dr. Sibly ${ }^{4}$ to be Upper Avonian, the lower portion being correlated definitely by the latter worker with the upper Seminula subzone $\left(S_{2}\right)$; he therefore justly separates the sandstones of the Forest of Dean from other "Millstone Grit" under the name of Drybrook Sandstone.

The Millstone Grit of Ifton cannot be placed palæontologically within narrow limits, but lithologically it resembles the Basal Grit of South Wales, which is the horizon also of the beds resting unconformably on the Carboniferous Timestone at Haverfordwest.

There is reason to believe ${ }^{5}$ that the Basal Grit is correlative with part of the Pendleside Series. When it is remembered that other rocks of the South-West Province included in the Millstone Grit are certainly later than all Avonian and Pendleside zones-though they may not be MiddleCoal Measures as suggested by R. H.Goode ${ }^{6}$ it can be seen how necessary it is to distinguish between the different components of the barren series, separating Limestone from Coal Measures, which has been given the useful name of Millstone Grit.

The areal extent of the unconformity remains to be determined. The break exists at the eastern and western ends of the North Crop of the South Wales basin, but is presumably absent at those intermediate places along the outcrop where radiolarian cherts are

I In "The Country around Haverfordwest" (Mem. Geol. Surv.), 1914, p. 151.

2 Quart. Journ. Geol. Soc, , vol. lxxiii, 1918, p. 111.

3 Quart. Journ. Geol. Soc., vol. lxi, 1905, pp. $251-2$.

4 Geol. Mag., 1912, p. 417 ; Geol. Mag., 1918, p. 25.

5 E. Dixon, "The Country around Pembroke and Tenby" (Mem. Geol. Surv.), 1921, chap. $x$.

6 Quart. Journ. Geol. Soc., vol. lxix, 1913, pp. 272, 275. 
developed at the base of the Millstone Grit. In Gower and South Pembrokeshire the junction is almost certainly conformable.

\section{Description of the Ifton Section.}

The exposures at Ifton, which lie $5 \frac{1}{2}$ miles south-west of Chepstow, are disused parts of a quarry north-west of the junction of the roads from Caerwent and Magor. The formations present in the quarry are :--

3. Trias.-Brown, buff, or red friable sandrock and loose sand, up to 6 feet in thickness, the lowest few inches littered with angular fragments, chiefly of Carboniferous Limestone, Millstone Grit and impure limonite. They rest on an even platform eroded across Limestone and Grit alike, and doubtless represent a sandstone that forms the base of the Keuper Marl in this district, resting immediately on the Dolomitic Conglomerate where the latter is present.

2. Millstone Grit.-Hard sandstone, partly quartzitic and occasionally somewhat pebbly, with soft shales weathering to clay, both rocks raddled by ferruginous waters, the shales to purplish tones. The few moulds of plant-fragments present are generally small and indeterminable, but a large stem, ${ }^{1}$ found in situ, has been identified by Dr. Kidston as a Carboniferous type, probably a Lepidophloios. The beds fill steep-sided channels and underground cavities, eroded in the Carboniferous Limestone, in the manner to be described later.

1. Carboniferous Limestone.-Limestones, chiefly oolites or amorphouslooking calcite-mudstones, with some "subsequent" (vein-) dolomite; in colour white, light-rrey, or various red tones owing to raddling. All the beds appear to be free from contemporaneously-deposited sand. The fossils, of which Seminula ficoides Vaughan is the most abundant, and the rock-types show that they belong to the Seminula Zone, a conclusion to which Dr. Vaughan had come prior to my visit. The Dibunophyllum Zone, which in its normal development is characterised by distinctive fauna and rock-types, is certainly not represented by any part of the limestone.

The relations of the formations are illustrated by Pl. II ( $a$ and $b$ ) and Figs. 1 and 2 ; the general structure shown by Pl. II $(b)$, the photographs for which and for Plate II $(a)$ were taken in 1909, may still be seen in the quarry.

In Pl. II $(a)$ a single Grit-filled channel in the limestone is cut across, practically at right angles to its trend, by the quarry-face; it is 22 feet deep from the base of the Trias, which rests at both sides on the enclosing limestone, to the bottom (marked by a hammer). The dark material above the broken white line is the Trias; its base, though somewhat uneven, crosses from limestone to Grit without any indication of post-Triassic subsidence. The sides of the channel are shown by a continuous white line. The lower two-thirds of the infilling is fine sandstone, in which bedding-planes are obscure except for some along the bottom, parallel to the broad base of the channel. The sandstone is hard, and unbroken by any subsidence since its consolidation. That its filling the channel dates from the Carboniferous is shown by its containing (at the point

1 In the Geol. Surv. Coll, at Jermyn Street Museum (Regd. No. E.D. 1791). 
marked with a black cross) the large stem of Lepidophloios? previously mentioned, the leaf-cushions impressing sandstone similar to, and continuous with, the rest of the rock. In the upper third, the thin sandstones and shales have a steady catenary bedding.

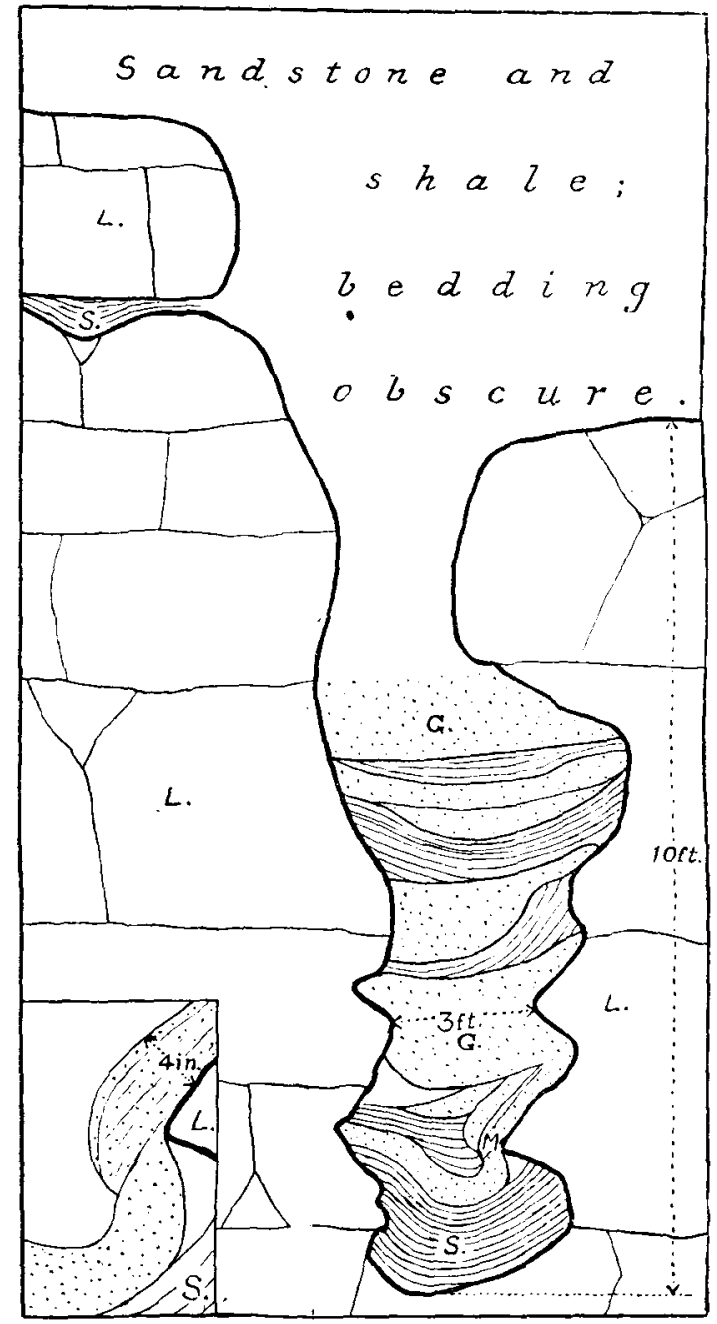

FIG. 1.-Diagrammatic sketch of a "pipe" in Carboniferous Limestone (L.), filled with sandstones (G.) and shales (S.). (Inset: detail of lamination in sandstone at M.)

The sides of the channel overhang in places, to a marked extent between the figure and the pick. The surrounding limestone, which occurs as almost horizontal beds-a well-marked layer runs along 
below the hammer-contains cavities filled with sandstone, or with sandstone and shale. The latter are similar to, but generally smaller than, that shown in Fig. 2. One near the shovel has been partly picked out with a white line, but the others do not contrast sufficiently with the enclosing limestone to show up in the photograph. Those filled with sandstone alone are difficult enough to delimit on the ground, as the sandstone has a calcareous cement and is firmly welded to the similarly-weathering limestone that encloses it.

Pl. II $(b)$ shows a wider extent of the junction of limestone and Grit, the distance from $A$ to $E$ being 50-60 yards. The base of the Trias (above and to the left of $B$ ) is shown by a broken black line. The surface of separation of Grit from limestone is marked, by continuous black lines, only where it is clear in the photograph; between the Grit-filled hollows $C$ and $E$ it was too complicated to be traced readily. For one thing undisturbed limestone has an awkward trick of poking up amid Grit where least expected. The masses in this position may be presumed to be remnants, isolated laterally by confluent Grit-filled hollows, somewhat.similar to the top $(B)$ of the limestone between the Grit-filled hollows $A$ and $C$, which appears to be surrounded by Grit. Doubtless $B$ is, or has been, continuous with the limestone below, and the strip of Grit, apparently below it, is either banked against it or fills a channel crossing it. In some cases, however, as in that of undisturbed limestone at $D$, the boundary with the Grit is most irregular, and no adjacent limestone is exposed.

Conversely, as in the limestone enclosing the channel shown in Pl. I (a), Grit appears repeatedly in the limestone below the black line, flling vertical "pipes" and irregular cavities. Generally the communicating passage with the main mass of Grit above is not to be seen, but one definite "pipe", shown in Fig. 1, is continuous therewith. The overlying Grit is seen on the right, and the bottom of the "pipe" is 10 feet below. The contents (sandstone and shale) have evidently remained undisturbed since their first introduction, as sand and mud, and consolidation. The $4 \mathrm{in}$. sandstone, shown in detail at the bottom of the figure, curves sharply in conformity with the steeply-sloping surface of the limestone-wall and with the shale filling the bottom of the "pipe", but is now quite hard.

A large, irregular cavity (Fig. 2), 6 yards in length, filled with sandstone and shale, of which the form was more than usually clear, was seen in the quarry-face opposite that shown in Pl. II (b). The sandstone occurs partly as a horizontal wedge, about 6 feet thick at the larger end, partly as thin laminæ interbedded with the shales. At one place small carbon-lined moulds suggest that plantfragments have been washed in with the sand, now represented by the sandstone. On the right the cavity is prolonged vertically downward as a funnel-shaped shale-filled "pipe". This was cleared for $3 \frac{1}{2}$ feet below the sandstone-wedge without being bottomed.

VOL. LVIII. - No. IV. 
The chief questions that arise are :-

1. Were the hollows in the limestone formed before or after the deposition of the beds spoken of as Millstone Grit?

2. What is the age of the so-called Millstone Grit?

1. The catenary bedding of the sandstones shown in Pl. II (a) suggests at first sight subsidence into a local hollow formed after their deposition. The remainder of the evidence is, however, overwhelmingly against this conclusion. The sandstones have been deposited as sand in their present position, and have not been disturbed since consolidation. They contrast strongly with the debris of Millstone Grit filling swallow-holes, both recent and preGlacial, in the Carboniferous Limestone at various places in South

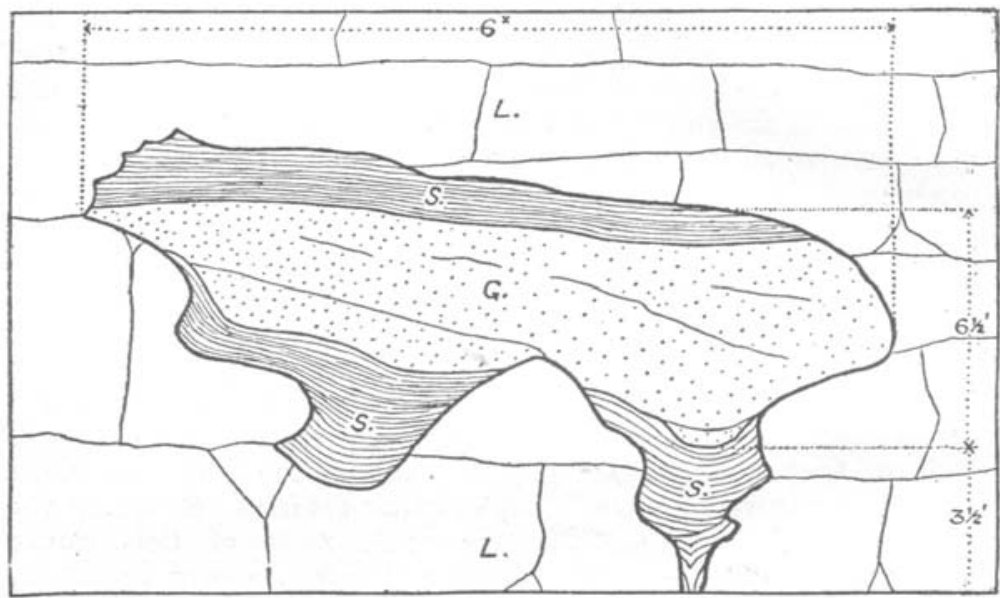

FIG. 2.-Diagrammatic sketch of a cavity in Carboniferous Limestone (L.), filled with sandstone (G.) and shales (S.).

Wales; in these the sandstones and shales are broken, or eren thoroughly shattered, and jumbled together. The evidence that the Ifton sandstones have not been disturbed since consolidation needs to be unearthed in the field to be fully appreciated. It consists partly in the unbroken character of the hard beds, straight and curved alike, which are too brittle to bend, partly in the fact that the wedge-like form of some and the minor details of the lamination of others (as at $M$, Fig. 1) have been obviously determined by adjacent limestone-surfaces, and partly in the firm welding of some to the enclosing limestone.

2. The Lepidophloios? was certainly deposited contemporaneously with the enclosing sandstone and was not part of a derived fragment. But this genus merely shows that the beds are Carboniferous. The lithological and stratigraphical evidence, however, is fairly conclusive. The choice of horizon lies between some part of the 
Upper Avonian, the Basal Grit of the Millstone Grit, and some part of the Coal Measures.

As previously mentioned sandstones are present to a greater or less extent in the Upper Avonian in the adjacent Bristol and Forest of Dean districts, and in the eastern part of the South Wales basin also. But these sandstones are invariably conformable with the underlying beds, and cannot, therefore, be compared with the Ifton sandstones.

It is harder to choose between the Basal Grit and the Coal Measures. Both formations have been proved to rest unconformably on the Carboniferous Limestone in adjacent regions: in the South Wales basin, about 14 miles to the west, in the case of the Basal Grit ; and in the Forest of Dean, ${ }^{1}$ at the same distance to the north-east, in that of the Coal Measures. It is probable, too, that the unconformities on both horizons have been preceded by "piping" of the Carboniferous Limestone. This has certainly happened prior to the deposition of the Basal Grit, and appears also, from Dr. Sibly's ${ }^{2}$ description, to have preceded the formation of the Coal Measures of the Forest of Dean.

In support of a Coal Measure age we have the presence of Coal Measures close by, Pennant Sandstone and coals having been proved ${ }^{3}$ in the Severn Tunnel near Southbrook, $2 \frac{1}{2}$ miles east of Ifton. On the other hand, the lfton sindstones resemble neither the Pennant, nor the Trenchard Upper Coal Measures, described by Sibly, that form the base of the Coal Heasures in much of the Forest of Dean. It is possible, of course, that what have been spoken of as two unconformities are really but one, accompanied by persistent overlap of the overlying basal beds between South Wales and the Forest of Dean. On this hypothesis the Forest of Dean would represent part of the margin of the South Wales basin, and the Ifton sandstones might be correlative with neither the Basal Grit, deposited, presumably soon after the uplift and subsequentsubsidence, in the interior part of the basin, nor with the Upper Coal Measures, laid down much later in the Forest of Dean. Simplicity has its charms, and the postulation of breaks in "conformable" series should be regarded as an unpleasant duty rather than a light mental exereise. But in this case it happens that a break between Middle and higher Coal Measures has been proved in Wyre Forest at no great distance north of the Forest of Dean. The hypothesis of a persistent overlap between South Wales and the Forest of Dean therefore does not help us. As a fact the Ifton sandstones so closely resemble the Basal Grit of South Wales that, in default of conclusive evidence to the contrary, we must refer them to that horizon and suppose, as a corollary, that there has been no overlap

1 T. F. Sibly, Geol. Mac., 1912, p. 420.

2 GEOT. MAC., 1918, p. 26 .

${ }^{3}$ Charles Richardson, Proc. Bristol Nat. Soc., ser. III, vol. v, 1887, p. 49, section. 
among the beds that have immediately overlain the Carboniferous Limestone for at least a dozen miles east of the main outcrop in South Wales. A determination of the age of the Coal Measures at the Severn Tunnel, which are exposed, so far as known, only in the half-tide rock called Lady Bench, would be both interesting and important; their relationship to the so-called Millstone Grit that was proved below in the Tunnel works we cannot hope to learn. This Millstone Grit appears, from the descriptions and section made by the first engineer ${ }^{1}$ of the tunnel and by one of his assistants, ${ }^{2}$ to have "piped" the underlying Carboniferous Limestone as do the Ifton sandstones.

A minor point is the question whether any of the Grit now present in Ifton quarry has been deposited in the light of day or whether it has all been laid down in cavities, the limestone-roof of which has been removed by the pre-Triassic denudation. The fact that some of the channels, such as that in Pl. II $(a)$ and $A$ in Pl. II $(b)$, which, from their relative positions in the quarry, are probably continuous one with the other, are large and widen upward may count for little, but the persistence of the Grit beneath the Trias for a distance of 50 yards, more or less at right angles to the trend of these channels, suggests deposition in the open.

\section{Conclusions}

The Carboniferous Limestone was eroded subærially prior to the deposition of the Ifton sandstones, the Dibunophyllum Zone presumably being removed and the Seminula Zone below irregularly worn into deep channels with steep, even overhanging sides, into vertical " pipes" descending an unknown depth into the limestone, and into every conceivable intermediate form of cavern and passage.

The sandstones and shales, with rare plant-remains, that were then deposited in and on the limestone were contemporaneous with the Basal Millstone Grit.

My cordial thanks are due to the Ifton Limestone Company, Ltd., for their courtesy in readily permitting me to examine the quarry and to publish this account, to the Director of H.M. Geological Survey for the photographs for the plates, and to Messrs. T. C. Hall and G. Maunsell for help in the field.

1 Charles Richardson, op. cit.

2 E. D. Jones, Proc. Geol. Assoc, vol. vii, 1881-2, p. 339. 